\title{
Krzysztof Kozłowski Między sceną a dziełem. O reformującej roli dramatów muzycznych Richarda Wagnera
}

\begin{abstract}
Kozłowski Krzysztof, Między sceną a dziełem. O reformującej roli dramatów muzycznych Richarda Wagnera [Between stage and work of literature. In the reforming role of Richard Wagner's musical dramas]. „Przestrzenie Teorii" 10. Poznań 2008, Adam Mickiewicz University Press, pp. 19-29. ISBN 978-83-232-1946-0. ISSN 1644-6763.
\end{abstract}

In Between stage and work of literature. In the reforming role of Richard Wagner's musical dramas the author tries to show that musical dramas of the German composer were actually important artistic events which could contribute to the understanding of the complex relations between the stage and the musical drama as preserved in the score. The lack of the unequivocally outlined conception of the work - incomplete at different levels and unspecified in its many aspects gave an impulse to numerous stage experiments which appeared to be of significance just from the point of view of the history of the theatre. And so the history of staging Wagner's dramas became a part of its history; Adolphe Appia, a Swiss reformer of the theatre was one of the first to find this regularity and tried to present it on stage using all the historical changeability of the latter.

Starając się zreformować współczesną sobie inscenizację, Adolphe Appia pisał:

Dramaty Wagnera przybliżyły operę do sztuki mówionej, ta zaś zmierza (pomijając naturalizm) do obalenia dawnych swych ograniczeń i sama wychodzi naprzeciw dramatowi muzycznemu. I oto, rzecz dziwna, okazuje się, że nasza inscenizacja nie odpowiada już wymogom ani jednej, ani drugiej strony. Komiczne operowe malowidła nie mają nic wspólnego z partyturami Wagnera (mimo iż wagnerowscy reżyserzy, w Bayreuth czy gdzie indziej, zdają się tego nie pojmować), a monotonne dekoracje sztuk mówionych nie zadowalają wyrafinowanej wyobraźni autorów dramatycznych. Wszyscy czujemy, że reforma jest konieczna, ale siły bezwładu spychają nas w te same wciąż koleiny ${ }^{1}$.

Jak można zauważyć, w oczach Appii decydujący impuls do reformy teatru pojawił się nie tyle $w$ programach teoretycznych, ile w dziełach sztuki, a ściślej mówiąc: w dramatach muzycznych Wagnera oraz - niedoprecyzowanej tutaj, jakkolwiek możliwej do rozpoznania - „wyobraźni

1 A. Appia, Jak zreformować naszq inscenizację, przeł. L. Kossobudzki, w: Dzieło sztuki żywej $i$ inne prace, wybór i noty J. Hera, wstęp J. Kosiński, Warszawa 1974, s. 66. 
autorów dramatycznych". Sławny reformator teatru zdawal się więc wychodzić od tego, co empiryczne. Fascynacja dramatami muzycznymi Wagnera sprawiła, iż zapragnął nadać im nowy kształt sceniczny, odpowiadający temu, co stanowiło ich najbardziej pierwotną cechę. I jakby tego było mało, w swej krytyce błędnie myślących ludzi teatru posunął się aż tak daleko, że domagał się stanowczo, by bronić - parafrazując jego słowa - Wagnera przed Wagnerem...2

Nie była to jednak myśl do końca nowa, ponieważ podobnej obrony "Wagnera przed Wagnerem" podjął się już - nieoczekiwanie - sam Wagner. Mimo że stwierdzenie to brzmi dość paradoksalnie, rodząc podejrzenie co do sensowności zawartej w nim treści, jest ono w gruncie rzeczy jak najbardziej prawdziwe, a co więcej: współbrzmi doskonale $\mathrm{z}$ doświadczeniem historycznym. Oto bowiem Wagner - po obejrzeniu na scenie w Bayreuth Pierścienia Nibelunga (1876) - przeżył wielkie rozczarowanie, które spowodowało, że nie zamierzał go już tam więcej wystawiać następną inscenizację tetralogii pokazano dopiero dwadzieścia lat później ${ }^{3}$.

Trudno jest dzisiaj odpowiedzieć jednoznacznie na pytanie, dlaczego tak się stało i co skłoniło najpierw Wagnera, a potem Appię do tak niezwykłego zachowania. Pewne podpowiedzi można odnaleźć u nich samych. W oczach Appii bowiem tym, co zaszkodziło Wagnerowi najbardziej, był jego zapał teatralny i pełen niejednoznaczności stosunek do teatralnego status quo. Inaczej - choć w myśl tej samej zasady - widział ten problem kompozytor. Rozumial on mianowicie, iż koncepcja bayreuthskiej inscenizacji nie odpowiadała bynajmniej temu, co znajdowało się w napisanych przez niego dramatach. Tak więc trudno mu się dziwić, kiedy w czasie pracy nad Parsifalem (we wrześniu 1878 roku) wpadł na pomysł tyleż konsekwentny, co szalony - pomysł wynalezienia... niewidzialnego teatru. W Die Tagebücher Cosimy Wagner zachowało się następujące świadectwo:

${ }^{2}$ W Dziele sztuki żywej pisal: „Wagner dokonal tylko jednej zasadniczej reformy. Za pomocą muzyki potrafił dać początek akcji dramatycznej, której caly ciężar - środek ciężkości - spoczywał wewnątrz bohaterów. [...] Wagner chciał więc przenieść ją na scenę, to znaczy ukazać naszym oczom i w tym miejscu poniósł klęskę. - Obdarzony jak żaden z jego poprzedników absolutnym wyczuciem w dziedzinie techniki dramatu, wyjąwszy zagadnienia związane $\mathrm{z}$ inscenizacją, Wagner wierzyl, że inscenizacja winna wynikać z tego niejako automatycznie; nie wyobrażał też sobie innej techniki dekoracyjnej niż ta, którą posługiwali się jego współcześni” - A. Appia, Dzieto sztuki zywej, przeł. L. Kossobudzki, w: Dzieto sztuki zywej $i$ inne prace, s. 160.

3 D. Mack, Der Bayreuther Inszenierungsstil 1876-1976, München 1976, s. 42-43 („100 Jahre Bayreuther Festspiele”, t. 7). 
„Ach”, zawołał [Richard Wagner - dop. K.K.], „przerażają mnie wszystkie ukostiumowane i wyszminkowane istoty; kiedy myślę o tym, że takie postaci, jak Kundry, miałyby wystąpić w masce, stają mi od razu przed oczyma te obrzydliwe festyny artystyczne; a skoro stworzyłem niewidzialną orkiestrę, chciałbym także wynaleźć niewidzialny teatr!” „I niesłyszalną orkiestrę”, dodał, kwitując pełne troski rozmyślanie humorem ${ }^{4}$.

Zarówno Wagner, jak i Appia zrozumieli wyjątkowość sytuacji, w jakiej się znaleźli. Wątpliwe tylko, czy wyszli poza intuicyjne przekonanie o odmiennej naturze hołubionych przez siebie dramatów w stosunku do dawnej opery5. Wiedzieli, iż zmiany, które chcieli wprowadzić, powinny być gruntowne i dotyczyć nie tyle sytuacji sztuki teatru jako takiej, ile tej konkretnej, stawiającej nowe wyzwania przed inscenizatorami. Również $\mathrm{w}$ tym wypadku inscenizacja pozostawała konstytutywnym składnikiem dzieła dramatyczno-muzycznego, które urzeczywistnia się dopiero na scenie, ukazując przy tym niestabilność swego istnienia. Carl Dahlhaus, opisując fenomen Wagnerowskiego dzieła sztuki, nie miał najmniejszych wątpliwości, iż mamy tu do czynienia z czymś całkowicie nowym ${ }^{6}$, niepodobnym do tego wszystkiego, co było wcześniej oczywistością, a co pojawiło się nie jako reakcja na rzekomą martwotę, w jaką popaść miała dawna opera7, lecz jako sprzeciw wobec włoskiej czy francu-

4 R. Wagner, Sämtliche Werke, t. 30: Dokumente zur Entstehung und ersten Aufführung des Bühnenweihfestspiels Parsifal, hrsg. von M. Geck und E. Voss, Mainz 1970, s. 34 .

5 O tym, że Appia pojmował dramaty Wagnera jako osobny gatunek dramatu, a nie tylko jako jednostkowy, choćby nawet najbardziej oryginalny wykwit artystyczny, mogą przekonać jego własne słowa. „Nie znamy - możemy przeczytać w Inscenizacji dramatu wagnerowskiego (1894) - obecnie innych przykładów dramatu wagnerowskiego poza dramatami Richarda Wagnera [...]" - A. Appia, Inscenizacja dramatu wagnerowskiego, przeł. J. Hera, w: Dzieto sztuki zywej $i$ inne prace, s. 27.

${ }^{6}$ Niezwykle trafnie ujął to $w$ odniesieniu do Tristana, pisząc, że jeśli już trzeba by się koniecznie zdecydować i odpowiedzieć na pytanie, czy Wagnerowska forma dramatyczno-muzyczna bardziej związana była z przeszłością niż z przyszłością sztuki, odpowiedź - ,ze względu na historyczne oddziaływanie dzieła" - musiałaby wypaść jednoznacznie na korzyść przyszłości. "Tristan - podsumowuje Dahlhaus - oznacza początek, a nie koniec”. C. Dahlhaus, Wagners "Kunst des Überganges”. Der Zwiegesang in „Tristan und Isolde”, w: Vom Musikdrama zur Literaturoper. Aufsätze zur neueren Operngeschichte, München Salzburg $1989^{2}$, s. 161.

7 „To - czytamy u Wagnera - co spostrzegł wokół siebie Rossini, w pełni rozkwitu swej bujnej młodości, było już tylko żniwem śmierci. Kiedy rzucił swe przenikliwe spojrzenie [...] na poważną operę francuską, tak zwaną operę dramatyczną, to zauważył pełne dziwnego powabu zwłoki, których nie byl już w stanie ożywić nawet sam [...] Spontini, ponieważ chcąc złożyć hołd samemu sobie, żywcem się zabalsamował. Gnany zdrowym instynktem życia Rossini zdarł tym zwłokom wspaniałą maskę z twarzy, tak jakby chciał wybadać przyczynę ich minionej chwały; lecz za przepychem tych dumnie przeslaniajacych wszystko szat odkrył to jedno tylko [...]: melodię. - Kiedy spojrzał na rodzimą operę włoską i dzieło spadkobierców Mozarta, nie dostrzegł znowu nic innego prócz śmierci - 
skiej tradycji operowej, które nie znały antynomii oryginalność - konwencjonalność i które zdominowały życie teatralne dziewiętnastowiecznej kultury europejskiej w stopniu wcześniej niespotykanym.

Dzieło to zrodziło się więc $\mathrm{z}$ ducha oporu i z głębokiego przekonania o nieodzowności odnowienia sztuki operowej. Wagner, który wypróbował w mlodości wszystkie inne drogi jako artysta teatru operowego ${ }^{8}$, połączył w całość tradycję muzyki symfonicznej i myślenie stricte literackie, oparte na dramacie jako condicio sine qua non formy muzycznej. Za tym, że wymagało to radykalnego otwarcia tejże formy na to, co pozamuzyczne, nawet jeśli miało ono charakter literacki, argumentował przekonująco w Über den Kunstcharakter des Wagnerschen Musikdramas Stefan Kunze:

mogło się to wydarzyć tylko dzięki radykalnemu otwarciu struktury muzycznej na zjawiska sceniczne, na akcję zewnętrzną i wewnętrzną. Oznaczało to najpierw wyzwolenie od już istniejących uwarunkowań muzycznych [...]. W ten sposób powiodło się doskonałe wtopienie dramatycznej akcji, a także dramatycznej mowy w tkankę muzyki. Od tego procesu wtopienia przybyło muzyce nowych sil. [...]

Muzyka do tego stopnia objęla władczo i wyraziście każdy szczegół imaginacyjnego zdarzenia scenicznego, że zdarzenie to prześwieca teraz przez muzykę, tak iż ona sama ulega gruntownej przemianie. Dramat słowny dał muzyce możliwość nabrania charakteru sztuki [podkr. - K.K.]. „Mój dramat zawsze łamie konwencje i stwarza nowe możliwości", powiedzial kiedyś Wagner. Sens tego tak słynnego zdania Wagnera o tym, że muzyka jest środkiem do celu dramatu, zdania, które interpretatorom Wagnera sprawilo tak wiele kłopotu, należałoby właściwie odwrócić. Albowiem dramat literacki był przede wszystkim środkiem do tego, by zamanifestować fakt, iż muzyka jako muzyka dramatyczna ma charakter sztuki. Jeszcze dosadniej: dramat byl konstrukcją pomocniczą do urzeczywistnienia muzycznego dzieła sztuki.

Można by ponadto pokazać, że dramat muzyczny - od form językowych aż do scenicznej organizacji, więcej, aż do tworzywa - był przykrojony do potrzeb muzyki. To właśnie dramat literacki zrodził sztukę muzyczną. I ujawnia się ona jak najbardziej nie tylko na pierwszym planie, chociażby przez lejtmotywy, lecz w równym stopniu w prowadzeniu deklamacji ${ }^{9}$.

śmierci w beztreściowych formach, $\mathrm{z}$ których życie uchodziło mu melodiq - melodią kiepską, z całym tym udawaniem charakteru sztuki, które musiało mu się jawić jako w całości obłudne, kiedy patrzyl na to, co w jego oczach było niegotowe, gwałtowne i połowiczne" R. Wagner, Oper und Drama, hrsg. und kommentiert von K. Kropfinger, Stuttgart $1994^{2}$, s. 43.

${ }^{8}$ Zob. F. Lippmann, "Die Feen" und "Das Liebesverbot”, oder Die Wagnerisierung diverser Vorbilder, w: Wagnerliteratur - Wagnerforschung. Bericht über das WagnerSymposium München 1983, hrsg. von C. Dahlhaus und E. Voss, Mainz i in., s. 14-46. Zob. K. Kozlowski, Teatr i religia sztuki. "Parsifal" Richarda Wagnera, Poznań 2004, s. 38.

${ }^{9} \mathrm{~S}$. Kunze, Über den Kunstcharakter des Wagnerschen Musikdramas, w: Richard Wagner. Von der Oper zum Musikdrama. Fünf Vorträge, hrsg. von S. Kunze, Bern-München 1978, s. 19-20. 
Znaczy to, że powstała forma dramatyczno-muzyczna, której opis wymaga rozpatrywania całości przedstawienia artystycznego $\mathrm{z}$ podwójnej perspektywy: $\mathrm{z}$ jednej strony $\mathrm{z}$ punktu widzenia teatrologii i z punktu widzenia muzykologii - z drugiej. Każda próba wyłączenia którejś z nich została uznana przez Kunzego za „złe alibi badacza"10. Nazwał je złym, ponieważ - miast przybliżać do fenomenu tej formy - czyni ją omal niedostępną. Sytuacja stała się, jego zdaniem, tak trudna, że nawet rzetelne uwzględnienie obydwu perspektyw analitycznych pozwala co najwyżej wykryć jedność koncepcji twórczej, nie wytwarzając bynajmniej poczucia, że obcujemy z dziełem artystycznym, które zostało skomponowane jako opus perfectum et absolutum. Przeciwnie, wszystko przemawia za tym, iż chodzi tu o dzieło, które nie zostało „domknięte” na wszystkich poziomach $\mathrm{i}$ we wszystkich sferach swego istnienia. Dahlhaus, polemizując z koncepcją analityczną Alfreda Lorenza ${ }^{11}$, pojmował je jako work in progress, postulując jednocześnie idę hierarchiczności formy, choć podobnie jak dla Wagnera, który posługiwał się metaforyką akwatyczną ${ }^{12}$ - nie miała ona już dla niego waloru architektonicznego.

Forma muzyczna - czytamy w Wagners Konzeption des musikalischen Dramas jeśli została już zaprojektowana, urzeczywistnia się niejako hierarchicznie: motywy łączą się ze sobą w kompleksy albo grupy motywów, grupy w „okresy poetycko-muzyczne”, okresy w sceny lub części scen [...], sceny - w dramat. Jakoż forma - „architektoniczna” albo „logiczna” - nie jest zawsze jednakowo zarysowana na wszystkich stopniach hierarchii. „Zwartośc” grupy motywów w szczegółach może iść w parze z „otwartą" strukturą okresową, ze względnym ich nierozgraniczaniem; a to, jak się maja do siebie nawzajem wyrazistość i trwalość poszczególnych okresów, nie jest podporządkowane żadnej regule, lecz stanowi jeden z problemów interpretującej analizy form [...] [podkr. - K.K.]. Analogia części i całości nie może być w każdym razie zakładana tak po prostu, lecz stopień zgodności albo różnicy poszczególnych elementów dzieła musi być przebadany i rozumiany jako cecha charakterystyczna. I, jak się zdaje, nieprzypadkowo formalne zamknięcie okresu w Pierścieniu stoi czasami w sprzeczności do muzycznej jedności sceny, i odwrotnie [...]13.

Uzupełniając, warto przypomnieć okoliczność, iż dla Wagnera muzyka nie była celem, lecz środkiem do urzeczywistnienia dramatu, który

${ }^{10}$ S. Kunze, Richard Wagners imaginäre Szene, w: Dramatisches Werk und Theaterwirklichkeit, hrsg. von H.J. Lüthi, Bern 1983, s. 36 („Berner Universitätsschriften”, t. 28).

11 A. Lorenz, Das Geheimnis der Form bei Richard Wagner, t. 1-4, Tutzing 19662.

12 Zob. R. Wagner, Ein Einblick in das heutige deutsche Opernwesen, w: Späte Schriften zur Dramaturgie der Oper, ausgewahlt und mit einem Nachwort hrsg. von E. Voss, Stuttgart 1996, s. 131-159.

13 C. Dahlhaus, Wagners Konzeption des musikalischen Dramas, München i in. $1990^{2}$, s. 106. 
był przez niego widziany jako przejaw wyższego rzędu jedności muzyki, sceny i tekstu dramatycznego. Wszak muzyka została tu pomyślana i skomponowana w taki sposób, żeby jawiła się tylko w odniesieniu do konkretnej akcji scenicznej ${ }^{14}$.

Otwartość Wagnerowskiej formy dramatyczno-muzycznej stanowiła tym samym problem dla egzegetów kompozytora, którzy - chcąc ją uchwycić i opisać - musieli dokonywać interpretującej analizy form. Było to o tyle karkołomne, że rezultat stawał się trudny do przewidzenia. Poszczególne opisy formy albo próby zredukowania jej do dawnych schematów interpretacyjnych $z$ nauki form muzycznych - jak to miało miejsce w wypadku Lorenza, który sadził, iż odkrył tajemnicę tej formy ${ }^{15}$ - okazywały się nieporównywalne. Co ważniejsze, nie odpowiadały w ogóle na pytanie, czym jest Wagnerowski dramat muzyczny. Bo nie jest nim na pewno - przynajmniej w opinii Dahlhausa ${ }^{16}$ - ów dramatyczno-muzyczny konstrukt, którego status wolno by zrównać z Wagnerowskimi dramatami muzycznymi, pojmowanymi przez kompozytora jako dramaty tout court. Jak dodaje Dahlhaus, rozpatrywanie „formy dramatyczno-muzycznej" tych dramatów - jakkolwiek niezwykle ważne i zasadnicze dla kwestii czysto teoretycznych - nie wyczerpuje złożoności problema-

14 Służyć miala jej lepszemu osadzeniu na scenie i zapewnieniu całości skuteczniejszego oddziaływania, co - nieoczekiwanie - prowadzilo do częściowego odwrócenia jednej z tez doktryny Schopenhauera, którego jesienią roku 1854 Wagner przedkładał już zdecydowanie nad Feuerbacha. Jak zauważa Dahlhaus, Wagners Konzeption, s. 116, „w estetycznej kontemplacji, tak jak opisał ją Schopenhauer, w nielicznych momentach, w których odsłania się w sposób zdeformowany metafizyczna istota muzyki, akcja dramatyczna słabnie i zostaje zredukowana do schematu, a muzyka przenosi elementy świata zjawisk we właściwy sobie obszar snu. Kompozytorskiemu urzeczywistnieniu "na zewnątrz", przy którym muzyka jest środkiem do celu, jakim jest dramat, odpowiada jako estetyczna opozycja zwrócenie się «do środka».

Źródłem i «łonem dramatu» bardziej niż muzyka w kompozytorsko-empirycznym sensie tego wyrażenia jest muzyka w sensie metafizycznym. Fakt, że istnieją szkice muzyczne bez słów do Tristana, nie może być podstawą do błędnego rozumienia formuły dramatu jako "widzialnego czynu muzyki». Metafizycznej zawartości formuły nie dorównują bynajmniej skąpe możliwości historyczno-kompozytorskie, które nawet $\mathbf{w}$ Tristanie przedstawiają jedynie wyjątek, a nie regułę. Nie to, że powinno się przeczyć, jakoby Wagnerowska recepcja Schopenhauerowskiej filozofii, konwersja ku metafizyce muzyki, której w Operze $i$ dramacie nie ma jeszcze najmniejszego śladu, łączyła się z doświadczeniami kompozytorskimi. Metafizyczne pojęcie muzyki ma bez wątpienia swój korelat techniczno-kompozytorski, nie może być jednak traktowane jako równoznaczne $z$ empirycznym pojęciem muzyki".

15 Zob. K. Kozłowski, Dahlhaus - Kunze: dwuglos o dramacie muzycznym Richarda Wagnera, http://www.demusica.pl („Pismo Muzykalia”: Muzykalia IIL/3; materiały z III konferencji muzykologicznej organizowanej przez Stowarzyszenie De Musica, Warszawa, 24-25 listopada 2007 r.).

16 Tamże, s. 4-5. 
tyki, jaka tu występuje. Do pełni rozumienia potrzebny jest jeszcze wymiar inscenizacji teatralnej. Wszak Dahlhaus nieustannie przypominał, że "centralną kategorią estetyki dramatu muzycznego Wagnera jest urzeczywistnienie" 17 . W Richard Wagners Musikdramen pisał o tym tak: „Dramat, o jakim marzył Wagner, spełnia się w akcji scenicznej, w której język i muzyka otrzymują także charakter gestyczny i sceniczny"18. Teatr nie jest zatem ilustratorem dramatu, ukazującym gotowe dzieło na scenie, lecz - by posłużyć się formułą Dobrochny Ratajczakowej - bierze na siebie rolę jego interpretatora ${ }^{19}$. Innymi słowy, Wagnerowski dramat muzyczny staje się zaczynem nowego rodzaju sztuki teatru20, ustanawiając też nową relację między dziełem a sceną. Nie jest to relacja statyczna, lecz w pełni dynamiczna, oparta na interakcji, jako że nic nie jest tu do końca gotowe.

I właśnie ta okoliczność tłumaczy, dlaczego Cosima Wagner, nie rozumiejąc propozycji scenograficznej Appii, odrzuciła ją jako niebezpieczną dla tradycji bayreuthskiej21. Wychodziła bowiem z założenia, że dramaty muzyczne Wagnera są gotowymi dziełami, które - pojmowane zgodnie $\mathrm{z}$ estetyką XIX wieku operującą $\mathrm{w}$ odniesieniu do dzieła sztuki starym schematem dusza - ciało, a tym samym gloryfikującą pojęcie „wierności” - jawią się na scenie, w zmiennych formach inscenizacyjnych, jako nienaruszone $w$ swej substancji. Są one doskonałe $i$ niezmienne, spoczywają - by tak rzec - w swej istocie i nie mogą być niczym innym, niż są.

Jeśliby się jednak - pisze Dahlhaus - uznało inscenizację za część dzieła samego, jako dzieła tegoż zamknięcie i zakończenie, to byłoby się zmuszonym albo uznać za własną ideę niestabilności dzieł sztuki - ideę, którą można zaakcepto-

17 C. Dahlhaus, Richard Wagners Musikdramen, Stuttgart 1996³, s. 225.

18 Tamże.

19 D. Ratajczakowa, Teatr jako interpretator dziela literackiego, w: Problemy teorii dramatu i teatru, wybór i oprac. J. Degler, Wrocław 1988, s. 418.

20 Stoi to $w$ całkowitej sprzeczności z tym, co we wstępie do pism wybranych Adolphe'a Appii sądzil o dramatach Wagnera Jan Kosiński, Appia, scenograf - muzyk, w: A. Appia, Dzieto sztuki żywej $i$ inne prace, s. 18, pisząc: „Dzis, z perspektywy półwiecza od ukazania się Dzieła sztuki żywej i trzech ćwierci wieku od pierwszej broszury, Inscenizacji dramatu wagnerowskiego, doznajemy w zetknięciu z tymi tekstami uczuć zapewne dość mieszanych. Obie miłości życia Appii, obie idee, którym to życie poświęcił, należą już do historii. Ani Wagner ze swoim Wort-Ton-Drama, mającym być syntezą sztuk, ani Jaques Dalcroze ze swoją rytmiką nie stanowią od dawna haseł wywoławczych twórczej myśli teatralnej. Wielka przygoda Wagnera okazała się monumentalną pomyłką, a w każdym razie nie stała się tym, za co miał ją Appia, to jest modelem dramatycznym dla całej epoki".

${ }^{21}$ Inna sprawa, że teorię Appii znała z drugiej ręki. Przedstawił ją Cosimie - niestety - nie kto inny jak Houston Stewart Chamberlain. W przeciwieństwie do Appii Cosima rozumiała światło jako cos, co wytwarza na scenie nastrój-D. Mack, op. cit., s. 10. 
wać i pojąć jedynie z trudem, ponieważ stoi ona w sprzeczności z wyobrażeniem, że do wielkości jakiegoś dzieła przynależy to, by być wyniesionym ponad historię - albo też ulec sztywnemu tradycjonalizmowi, który neguje historię lub się jej przeciwstawia, usiłując także wraz z dziełem uchronić przed zmianą inscenizację tegoż dzieła, która byłaby przemianą istoty, a nie tylko formą przejawiania się tej istoty. Estetyczna maksyma, że nie wolno naruszyć litery jakiegoś dzieła sztuki, jeśli się nie chce jednocześnie upośledzić jego ducha, w bayreuthskiej tradycji dramatu muzycznego została przeniesiona $z$ tekstu literackiego i muzycznego na inscenizację 22 .

Jest to pogląd, który - nawet z punktu widzenia nowoczesnej myśli teatrologicznej - brzmi bardzo rewolucyjnie, w oryginalny sposób ukazując relacje między sceną a Wagnerowską „formą dramatyczno-muzyczną, która - nie będąc wszakże dramatem w ścisłym sensie, o jakim mówił Wagner, a marzył Appia - sytuuje się gdzieś „pomiędzy”. Nie jest ona jeszcze dramatem i nie jest już spójnym „projektem wykonawczym”23, pozwalającym na mniej lub bardziej dowolne i niezależne od siebie inscenizacje. I niepodobna temu zaprzeczyć, bo inscenizacja wagnerowska nie może być zwyczajnym scenicznym wystawieniem „dzieła, które jako tekst językowy i muzyczny byłoby już «dziełem», w sobie spoczywającą strukturą"24. Wręcz przeciwnie, „[...] historia inscenizacji jest historią dzieła, historią tego, a nie innego, zmieniającego się dzieła"25, co znaczy między innymi, że nadaje ona kierunek jego interpretacji, który był nie tyle przez kompozytora narzucony lub przewidziany, ile postulowany. Wagner odwrócil się wprawdzie od tego, co zobaczył w teatrze, ale nie zakazał samego inscenizowania swoich dzieł. Ich obecność w teatrze stanowiła dlań prawdopodobnie gwarancję reformy tegoż teatru, jako że reformująca funkcja dramatów muzycznych Wagnera była tu funkcją prymarną.

Odczuł to mocno Appia, toteż jego projekty zreformowania teatru miały rys zarówno biograficzny (fascynacja Wagnerem), jak i teoretyczny. Otworzyła się przed nim przestrzeń innego teatru, któremu warto się było poświecić. Wagner natomiast stał się dlań synonimem nowoczesności przyciągającej do niego tych wszystkich, który rozumieli konieczność zmian w teatrze. Czy była to Wielka Reforma? Jest to mało prawdopodobne, kryło się tu jednak coś wyjątkowego i wymagającego głębszej refleksji. Wciąż jeszcze trudno wyjaśnić dynamikę rozwoju Wagnerowskiej inscenizacji i wpływu tejże inscenizacji na praktykę we współczesnym

22 C. Dahlhaus, Richard Wagners Musikdramen, s. 226-227.

${ }_{23} \mathrm{~J}$. Ziomek, Projekt wykonawcy $w$ dziele literackim a problemy genologiczne, w: Powinowactwa literatury. Studia i szkice, Warszawa 1980, s. 114 i n.

${ }^{24}$ C. Dahlh a us, Richard Wagners Musikdramen, s. 226.

25 Tamże. 
teatrze operowym. Skoro więc nie była to wielka reforma, odmienna od tego wszystkiego, co było wcześniej związane $\mathrm{z}$ istotą teatru, to może była to reforma po prostu tym tylko różniąca się od pozostałych, iż podyktowana została specyficzną sytuacją historyczną $i$ chęcią inscenizowania tego, co się kochało i za co chciało się walczyć, rzucając wyzwanie Cosimie Wagner i jej kręgowi26. Odpowiedź musi pozostać w zawieszeniu. Appii - abstrahując między innymi od jego inscenizacji przygotowanej dla Toscaniniego - nie było dane zobaczyć swych projektów Wagnerowskich na bayreuthskiej scenie, wzniesionej po to, by celebrować ideę teatru jako święta ${ }^{27}$. Nie mógł się zatem przekonać, jak bardzo zmienia się dzieło Wagnera w przestrzeni Festspielhausu i jak ściśle wiąże się ono z każdorazowo innym, acz współczesnym obrazem świata. Innymi słowy, nie doświadczył on głośnych sporów o inscenizację, które znajdowały tam zawsze nieoczekiwany i szczęśliwy finał. Wywołał co najwyżej sprzeciw, natrafiając na opór nie do pokonania. I dodajmy raz jeszcze: zrozumiały $\mathrm{z}$ punktu widzenia inscenizacyjnego stylu bayreuthskiego, lecz sprzeczny $z$ dramatami Wagnera, które usytuowały się gdzieś między sceną a dziełem, oczekując wciąż nowych inscenizacji mogących nadać im kształt i domykać częściowo choćby to, co w nich pozostawało otwarte.

Spełnienie takie stało się na pewno udziałem Wielanda Wagnera i Patricka Chéreau. Inscenizacje obydwu tych twórców przeszły do historii bayreuthskiej sceny jako dokonania epokowe, wyznaczając na wiele lat sposób myślenia o Wagnerowskiej inscenizacji. Po krótkim, choć gwałtownym sprzeciwie doceniono ich niewątpliwą wartość artystyczną, co umocniło tylko recepcyjną cliché28. Znamienne przy tym, że - przygotowując antologię pism Appii - nie dostrzegł tego Jan Kosiński, pisząc w podsumowaniu rozważań o Wagnerze, iż ,teatr muzyczny, wbrew wysiłkom jednostek, do naszych dni pozostal w praktyce zakurzonym przybytkiem werystów"29. A przecież wystarczyło tylko odwołać się do wagnerowskich inscenizacji Wielanda Wagnera, który w roku 1951 zaproponował inscenizację Parsifala wystawianą i graną niemal nieustannie $\mathrm{w}$ sezonach festiwalowych aż do roku $1973^{30}$. Zmieniając się z roku

${ }^{26}$ W. Schüler, Der Bayreuther Kreis von seiner Entstehung bis zum Ausgang der wilhelminischen Ära. Wagnerkult und Kulturreform im Geiste völkischer Weltanschauung, Münster 1971, s. 52-77.

27 L. Lucas, Die Festspiel-Idee Richard Wagners, Regensburg 1973 („100 Jahre Bayreuther Festspiele", t. 2).

${ }_{28}$ C. Dahlhaus, Richard Wagners Musikdramen, s. 232.

${ }^{29}$ J. Kosiński, op. cit., s. 18.

${ }^{30}$ D. Mack, op. cit., s. 21. Wieland usunąl ze swego przedstawienia słowo „Bühnenweihfestspiel”, chciał bowiem inscenizować „ludzkie misterium o miłości i śmierci, o zba- 
na rok, nabierała ona wciąż nowych znaczeń, nie kwestionując spójności obrazów scenicznych i interpretacji mitów zgodnie z zasadami wypracowanej przez Carla Gustava Junga „psychologii analitycznej”31.

Prawda jest jednak jeszcze gorsza. Kosiński nie dostrzegł ani specyfiki wagnerowskiego teatru, ani jego najsłabszego punktu. Zdawał się sądzić, że wystarczyć tu mogą sugestywne inwektywy („teatr muzyczny [...] pozostal w praktyce zakurzonym przybytkiem werystów"32). Gdyby się zastanowił i poświęcil więcej refleksji samym dramatom muzycznym, być może, doszedłby do wniosku, że tym, co było w projekcie Wagnera najsłabsze, jest właśnie ów niezbędny warunek powstania dzieła - inscenizacja. Bo też - jak przypomina Dahlhaus, analizując problemy Wagnerowskiego dramatu muzycznego - zarzuty, jakie postawiono Wielandowi po premierze Parsifala, były jednocześnie i słusznie, i niesłusz$n^{33}$. Należy to rozumieć $w$ ten sposób, że uzasadnione były opinie, iż odszedł on od projektu zapisanego w partyturze Wagnera, negując całkowicie jako martwą przeszłość stworzone przez kompozytora „przedstawienie", i pozwolił sobie na wypracowanie czegoś zasadniczo nowego. A skoro tak, to nietrudno dowieść, iż zarówno jedno, jak i drugie nie może być nigdy trwałe. Każda inscenizacja jest wyłącznie tymczasowa. Wprawdzie żąda jej forma dramatyczno-muzyczna, która chce stać się dziełem w przestrzeni sceny, ale zarazem dopełniająca całości Gesamtkunstwerku inscenizacja jest jego najsłabszym składnikiem. „Sceniczne przedstawienie - podsumowuje Dahlhaus - gestyka nie jest - chociaż została zaprojektowana przez Wagnera - w równym stopniu dziełem albo elementem składowym jakiegoś dzieła jak muzyka lub język"34. W przeciwieństwie do muzyki i języka nie jest ona tekstem. Można ją zapisać, ale nie da się jej potraktować jak tekstu. Dlatego też błędny jest postulat wierności scenicznej. Nie można przywrócić czegoś, co przynależało do stylu inscenizacyjnego, który jest dzisiaj martwy. Pozostaje jedynie stworzyć coś nowego, ze świadomością jednak, że i to wkrótce stanie się ciężarem, którego trzeba się będzie pozbyć. Ujawnia się tu nie tylko istota Wagnerowskiego dramatu muzycznego, poruszającego się nie-

wieniu i dobru" (tamże, s. 21). W ciągu 23 lat jego inscenizacja została pokazana aż 101 razy i okazała się najlepszym dowodem na teatralne przejście stylistyczne od reprezentacyjności do sugestywności.

31 Na tym jednak nie koniec. Zwolennicy tezy Kosińskiego mogliby się przekonać zaledwie dwa lata po jego śmierci, jak ważna (nie tylko dla scen operowych świata) okazała się bayreuthska inscenizacja Pierścienia Nibelunga przygotowana w 1976 roku przez Chéreau, którego obecne dokonania filmowe nadal pozostają w jej cieniu.

32 Zob. przyp. 29.

33 C. Dahlha us, Richard Wagners Musikdramen, s. 229.

34 Tamże, s. 229-230. 
skończenie między dziełem sensu stricto a sceną, lecz także natura każdego prawdziwego teatru, którego celem nie jest petryfikowanie konkretnego repertuaru lub choćby nawet największych dokonań teatralnych, lecz inscenizowanie i wystawianie dzieł. Istotą teatru jest jego funkcja, która spełnia się we wciąż nowych propozycjach. Chciałoby się na koniec powiedzieć, iż pielęgnować sztukę teatru to tyle, co dbać o dzieła, które nie powstają w pustce, lecz czerpią swą siłę $\mathrm{z}$ bogatych w formę projektów. 